\title{
From Social Media to Social Product Development: The Impact of Social Media on Co-Creation of Innovation
}
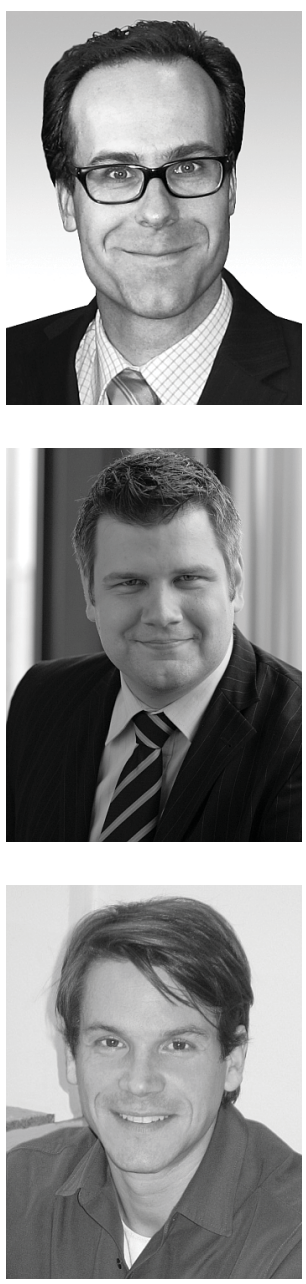

Frank Piller, Alexander Vossen und Christoph Ihl

Open innovation, co-creation, social media, social product development

Offene Innovation, Co-Kreation, soziale Medien, soziale Produktentwicklung

The objective of this paper is to discuss the impact of social media on customer co-creation in the innovation process. Customer cocreation denotes an active, creative and social collaboration process between producers and customers (users), facilitated by a company, in the context of new product or service development. We propose a typology of co-creation activities in order to develop conceptual arguments how social media can impact the relationships among customers involved in co-creation as well as the relationship between customers and the hosting firm. Social media can make economic-exchange relations more collaborative and social, but interestingly may also turn relations formerly based on social-exchange into "money markets" with strong competition among actors. As a result, we develop a set of questions that can lead future research in these regards.

Das Ziel dieses Aufsatzes ist es, die Bedeutung sozialer Medien für Customer Co-Creation im Innovationsprozess zu untersuchen. Der Begriff Customer Co-Creation bezeichnet in diesem Zusammenhang eine aktive, kreative und soziale Zusammenarbeit zwischen Herstellern und Kunden (Nutzern) im Rahmen der Entwicklung neuer Produkte oder Dienstleistungen. Wir schlagen eine Typologie von CoCreation-Aktivitäten vor, um systematisch zu argumentieren, wie soziale Medien die Beziehungen zwischen Kunden untereinander und die Beziehungen dieser Kunden mit Unternehmen beeinflussen können. Soziale Medien können auf der einen Seite ursprünglich ökonomisch und kompetitiv geprägte Marktbeziehungen zu mehr Zusammenarbeit führen (sie also „sozialer" machen), auf der anderen Seite aber auch einen ursprünglich sozialen Austausch in kompetitive Marktbeziehungen wandeln. Als Ergebnis entwickeln wir eine Agenda für weitere Forschung in diesem Themenfeld. 


\section{Introduction}

Today, the common understanding of the innovation process builds on the observation that firms rarely innovate alone and that innovation is a result of interactive relationships among producers, users, and many other different institutions (Laursen/Salter 2006; Reichwald/Piller 2009). Mansfield (1986) showed that innovation projects which are based to a large extent on external developments have shorter development times and demand less investments than similar projects based solely on internal research and development. As a result, the early Schumpeterian (1942) model of the lone entrepreneur bringing innovations to markets has been superseded by a richer picture of different actors in networks and communities (Laursen/Salter 2006). These actors are seen to work together in an interactive process of discovery, realization, and exploitation of a new idea. Innovative performance today is seen to a large extent as the ability of an innovative organization to establish networks with external entities.

Key actors in these networks are customers and users of a firm's products and services. There is a rich literature today that has investigated the role and contributions of customers and users in product innovation. Recently, the term co-creation has been established to denote special methods and strategies applied by firms to engage customers and users into their innovation process (Prahalad/Ramaswamy 2004). Customer co-creation describes as set of methods that establish an active, creative and social collaboration process between producers and customers (users) in the context of new product development (Roser et al. 2009; Piller/Ihl 2010). It denotes a paradigm shift from a manufacturer-active paradigm to a customer-active paradigm (von Hippel 2005).

At the same time, a similar paradigm shift has taken place in information and communication systems: from broadcast to social media (Kietzmann et al. 2011). The term social media denotes highly interactive platforms via which individuals and communities share, co-create, discuss, and modify user-generated content (Kaplan/Haenlein 2010). Examples for social media platforms include blogs (Blogger, Wordpress), microblogging (Twitter), collaborative wiki-projects (Wikipedia), forums (Harley Davidson user groups, Microsoft MSDN), professional networking sites (LinkedIn, Xing), and social networks (Facebook, Google+) (Kaplan/Haenlein 2010; Cortizo et al. 2011). While the previously named applications are dominated by the use of text, further applications are dedicated to other forms of media, like photographs (Flickr, Picasa), videos (YouTube, Vimeo), or music tracks (last.fm, ccMixter). Social media today also have expanded into virtual worlds (Second Life) and online gaming (World of Warcraft, Farmville). Recently, a new field of applications in social media is based on the usage of mobile data and the fast adoption of smartphones (Nomad Social Networks, Foursquare).

These applications have been used by large and small firms to improve their internal operations and to collaborate in new ways with their customers, business partners, and suppliers. For companies, value comes not from the platform itself (which is the source of revenue for the platform provider) but from how a particular social media platform is used and from the information that is created and shared on these platforms (Culnan et al. 2010). Table 1 provides a brief overview of some of the outcomes that firms expect from engaging in social media. A key driver of additional value by social media is that they allow the formation of online customer communities. However, beyond the attraction of a critical mass of participants who engage with the firm or other community members on an ongoing basis, firms also have to develop dedicated processes to benefit from the content 
created by its customers. Without this second condition, social media is not creating value for a firm (Culnan et al. 2010). We will illustrate some of these processes in the context of new product development in Section 3 of this paper.

\begin{tabular}{|l|l|}
\hline \multicolumn{1}{|c|}{ Activity } & \multicolumn{1}{c|}{ Motive of usage } \\
\hline Marketing (advertising, PR) & $\begin{array}{l}\text { Drive traffic, viral marketing, customer loyalty, customer } \\
\text { retention }\end{array}$ \\
Sales & $\begin{array}{l}\text { Increase revenue } \\
\text { Customer Service/Support }\end{array}$ \\
Croduct development & Increase fit to market, cost savings \\
\hline
\end{tabular}

Table 1: Motives of companies to engage in social media applications (based on Culnan et al. 2010, 244)

Beyond its impact on the individual firm, social media applications also influence industry structure on an aggregated level. Social media have been shown to strongly shift the power in established market structures (as in the case of the traditional media industries), to create new markets (as in the case of mobile applications), and to influence competitive behavior in established markets (empowerment of customers, word of mouth) (Kaplan/ Haenlein 2010). While it is commonly believed that social media usage has a huge potential for companies, it also offers a lot of traps to fall in. Social media offers customers a platform for easily engaging in bad word-of-mouth which can lead to a threat for a company"s image. An already classic illustration is the case of United Airlines. The Airline was hugely affected by a viral video composed by a musician whose guitar was broken on a United flight (Tripp/Grégoire 2011). Through social media, his bad word of mouth was not only shared among his friends and family, but with about 10,000,000 users on YouTube. This example highlights the risk for companies arising with the occurrence of social media. As a consequence, companies nowadays engage in strict social media monitoring and have published social media guidelines to manage such a behavior.

The idea of our paper is to systematically discuss how social media is enabling processes along the new product development function of a firm. Our focus will be on their impact on customer co-creation. Intuitively, both concepts are closely related. Many examples of customer co-creation in the innovation process are based on applications of social media. Consider Starbucks Ideas, a well-popularized platform where customers can share feedback, but also generate new offerings in form of an active dialogue among each other or with the company's management (Gallaugher/Ransbotham 2010; see di Gangi et al. (2010) for a study of a similar system at Dell Computers). This platform is entirely based on social media applications like online forums and a wiki system. In Germany, the intermediary "UnserAller" uses a Facebook App to engage hundreds of users in idea generation with consumer goods companies. According to their founder, Catharina van Delden, their entire business model would have not been possible without the advent of social media technology that is freely available and allows the connection with millions of users by tapping into established user communities and enabling communications among them at almost no cost (Reichwald/Piller 2009). 
The objective of our paper is to complement this anecdotal evidence with a theoretic perspective that can explain the impact of social media on co-creation. We build on Fiske's (1992) relational theory and a conceptualization of markets by Heyman and Ariely (2004). We argue that the rise of social media tremendously impacts the relationships among co-creating customers as well as the relationship between those customers and the focal firm. Therefore, we distinguish between co-creation methods in competitive "money markets”, which rely on economic exchange relations (by offering monetary incentives), and methods in "social market" relying on social-exchange relations (by offering nonmonetary incentives). We propose that the usage of social media in customer co-creation is a double-edged sword, with positive and negative effects. However, these effects vary for both kinds of relationships and for the different co-creation methods. We suppose that for customer-customer relationships the introduction of social media is beneficial, while for customer-firm relationship it bears new risks. For methods that rely on economic-exchange relations, the introduction of social media could actually push those methods more towards a "social market", while for the methods based on social-exchange, social media could drive them more into "money market".

The remaining of this paper is organized as follows. In the next section, we will review the integration of customers and users in the innovation process and provide an overview of the concept of customer co-creation. We present a typology of different forms of customer co-creation. ${ }^{1}$ Using this typology, we will then systematically discuss the impact of social medial on customer co-creation, using the market conceptualization by Heyman and Ariely (2004). For each type of co-creation, we develop a set of questions that may lead future research in this field.

\section{Customer co-creation}

Recently, the term open innovation has been used to characterize a system where innovation is not solely performed internally within a firm, but in a cooperative mode with other external actors (Reichwald/Piller 2009). Open innovation is opposed to closed innovation, in which companies use only ideas generated within their boundaries, characterized by big corporate research labs and closely managed networks of vertically integrated partners (Chesbrough 2003). Open innovation can be defined as the "use of purposive inflows and outflows of knowledge to accelerate internal innovation, and expand the markets for external use of innovation, respectively. [...] firms can and should use external ideas as well as internal ideas, and internal and external paths to market, as they look to advance their technology" (Chesbrough/Crowther 2006, 222). In this paper, we will focus on customers and users as external sources of knowledge in a firm's innovation process. While open innovation has been established as an umbrella term incorporating very different forms of external actors in formal and informal relationships which contribute to a firm's innovation process, the term "customer co-creation" recently has been used to specifically characterize firm-driven strategies of open innovation with customers.

1 Acknowledgements: An earlier version of this typology has been developed for a report on customer cocreation for the European Commission (Piller/Ihl 2010). Earlier versions of our typology have been published in Ihl/Piller (2010) and Piller et al. (2011). We are grateful for grants supporting this research by the NRW Ziel.2 Project OpenIsa, funded by the European Social Fund (ESF). 


\subsection{Definition}

The term customer co-creation denotes a product development approach where customers are actively involved and take part in the design of a new offering (Wikstroem 1996; Piller 2004; Prahalad/Ramaswamy 2004). More specifically, customer co-creation has been defined as an active, creative, and social process, based on collaboration between producers (retailers) and customers (users) (Roser et al. 2009; for extended reviews of the active role of customers in the innovation process refer to von Hippel 2005; O'Hern/Rindfleisch 2009; Piller/Ihl 2010). The idea of co-creation is to actively involve customers in the design or development of future offerings (Ramirez 1999), often with the help of tools that are provided by the firm.

Co-creation activities are performed in an act of company-to-customer interaction which is facilitated by the company. The manufacturer is either empowering its customers to design a solution by themselves or is implementing methodologies to efficiently transfer an innovative solution from the customer into the company domain (Seybold 2006; Tapscott/Williams 2006; Reichwald/Piller 2009). Examples for methods include ideation contests (Piller/Walcher 2006; Terwiesch/Xu 2008), lead user workshops (von Hippel 1988, 2005), consumer opinion platform (Hennig-Thurau et al. 2004), toolkits for user innovation (Thomkelvon Hippel 2002; von Hippel/Katz 2002), co-design toolkits (Franke/Piller 2004), or communities for customer co-creation (Franke/Shah 2003; Füller et al. 2008). The main objective is to enlarge the base of information about needs, applications, and solution technologies that resides in the domain of the customers and users of a product or service. This information can be used to increase the "fit to market" of a new offering, hence decreasing the risk of product flops, or to enhance the innovativeness of an offering, hence increasing its potential to capture the monopolistic rents which are typical for a radical innovation (Reichwald/Piller 2009).

\subsection{Co-creation versus market research}

At this point, we have to make an important differentiation between customer co-creation and conventional market research in new product development (Fredberg/Piller 2011). In market research, companies ask a representative sample of customers for input to their innovation process. In the early stages of an innovation project, customer preferences or unmet needs are identified via surveys, qualitative interviews, or focus groups ("voice of the customer" methods, Griffin/Hauser 1993). In the later stages of an innovation project, different solutions or concepts are presented to customers so they can react to proposed design solutions. For example, a manufacturer may recruit "pilot customers" or "beta users". These customers are observed and regularly surveyed to use their experiences and ideas for improvements of the prototype product before launching it in the general target market (Dolan/Matthews 1993). However, all of these approaches stay in the "manufacturing active paradigm" (von Hippel 1978) and build on feedback from representative samples of customers on statements or propositions made by the firm.

A more recent form of market research, but no active form of co-creation in our understanding either, is to "listen into" the customer domain by analyzing existing customer information from diverse input channels like feedback from sales people, analyzing the sales data from the last season, internet log files, or research reports by third parties (Dahan/ Hauser 2002). Here, social media applications have created a huge additional input can- 
nel. In this context, especially the method of netnography is noteworthy (Kozinets 1998, 2002). Netnography is "a new qualitative research methodology that adapts ethnographic research techniques to study cultures and communities that are emerging through computer-mediated communications" (Kozinets 2002, 62). Compared with other methods, it is less time consuming, potentially less obtrusive, and less costly (Langer/Beckmann 2005). Nethnography used to primarily analyze the observation of textual discourse. Here, modern approaches to text mining and content analysis have expedited the coding and analysis of data. However, social medial applications also allow users to easily add pictures or video to their content, enhancing the richness of the content that can be extracted from user communities. Bartl and Ivanovic (2010) present a good case study of the application of netnography at Beiersdorf (Nivea), where the analysis of existing user content in social media applications (twitter, Facebook comments, and user forums) has provided this company access to radical new customer insights which resulted in the successful launch of a new line of cosmetic products.

\subsection{A typology of co-creation}

Within our definition of customer co-creation as an active, creative, and social collaboration process between producers and customers in the context of new product development (Roser et al. 2009; Piller/Ihl 2010), we can distinguish different modes how customers can contribute to innovative activities of the firm. Customer co-creation is a multifaceted phenomenon. A conceptual typology of customer co-creation shall help to structure the relationships and ties between firms and customers in the innovation process.

The first dimension of our typology is based on the kind of information that shall be provided. In every innovation process, firms face various sources of uncertainty with regard to their technological and managerial capabilities and the target markets. Thomke (2003) names technical, production, need, and market uncertainty. To reduce these uncertainties, firms need to access and transfer different types of information (Cassiman) Veugelers 2006). In a generic framework, this information can be divided into two groups (Ogawa 1998; von Hippel 1998; Diener/Piller 2010):

- Information on customer and market needs (need information), i.e. information about preferences, needs, desires, satisfaction, motives, etc. of the customers and users in the target market. Better access to sufficient need-related information is increasing in the effectiveness of the innovation activities. It reduces the risk of failure. Need information builds on an in-depth understanding and appreciation of the customers' requirements, operations, and systems.

- Information on (technological) solution possibilities (solution information), i.e. information about how to apply a technology to transform customer needs into new products and services best. Access to solution information is primarily addressing the efficiency of the innovation process. Better solution information enables product developers to engage in more directed problem-solving activities in the innovation process.

The second dimension of our typology builds on the incentives that drive external actors to participate in a firm-driven innovation activity. Remember that co-creation is a voluntarily form of firm-customer interaction. Hence, it has to be motivated by dedicated incentives so that potential participants are willing to engage in a co-creation offering. Earlier research has been shown that customers are either motivated by extrinsic benefits (money, recognition, reputation) or intrinsic benefits (social status, task fulfillment, altruism) 
(Füller 2010). Building on Fiske's relational theory (1992) and a conceptualization of markets by Heyman and Ariely (2004), we can distinguish between co-creation methods in "money markets" which rely on economic-exchange relations (by offering monetary incentives) and methods in "social market" that rely on social-exchange relations (by offering non-monetary awards):

- The economic-exchange category consists of methods where a monetary incentive is exchanged for ideas and solutions (e.g. Terwisch/Xu 2008; Jeppesen/Lakhani 2010; Boudreau et al. 2011). Participants compete among each other to get a maximum share of a limited award.

- The social-exchange category consists of methods where participants engage in innovative behavior for reasons like fun or task achievement (von Hippellvon Krogh 2003, 2006), or for outcome expectations that enhance their own use experience or that of others (Harhoff et al. 2003).

Combining these dimensions, the structure in Figure 1 evolves that can distinguish four methods of co-creation in the innovation process. We will introduce these methods in more detail in the following section, when we discuss the impact of social media on the application of these methods. Note that in their basic forms, these methods do not rely on social media but are proprietary methods of innovation management.

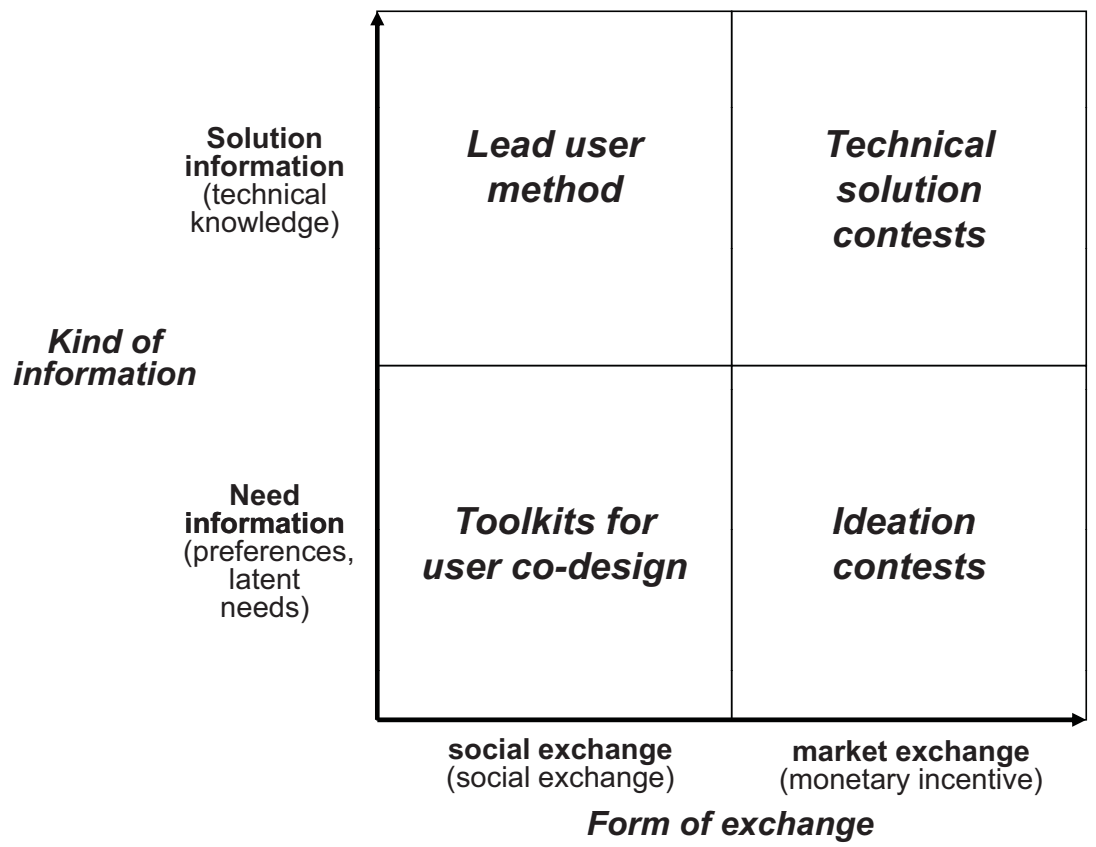

Figure 1: A typology of co-creation activities

\section{Social media and its impact on relationships within co-creation in new product development}

Our central assumption is that the rise of social media tremendously impacts the relationship between customers and firms as well as the relationships among the customers them- 
selves. As highlighted earlier, social media has the capability of changing market structures and relations between market actors to a large extent. One interesting aspect is the change in the customer-firm relationship due to enhanced access to information for both sides. Customers can get a clearer impression on firms' activities and products by e.g. visiting a firm's Facebook page, but the firm in return gets additional valuable information about the visitor's social network profiles. Further, it is not only the customer-firm relation, but also the customer-customer relation that is affected. Customer can communicate, share knowledge, and find people with similar interests far easier. In turn, we expect that social media usage could have a great impact on relationships within each method of co-creation. In the following, we will have a closer look on the effect of social media on co-creation in both monetary-exchange relations as well as in social-exchange relations. In addition, we will examine the impact of social media on the four co-creation methods differentiated in our typology.

\subsection{Social media impact on the lead user method}

The lead user concept is a method to get access to need and especially solution information in the concept generation stage of an innovation project. Research has shown that many commercially important products or processes are initially thought of innovative users rather than of manufactures (von Hippel 1988, 2005). Especially when markets are fast-paced or turbulent, so called lead users face specific needs ahead of the general market participants. Lead users are characterized as users who (1) face needs that will become general in a marketplace much earlier before the bulk of that marketplace encounters them; and (2) are positioned to benefit significantly by obtaining a solution for those needs (von Hippel 1988). Lead users originally have been seen as being motivated intrinsically to innovate, performing the innovation process autonomously and without an interaction with a manufacturer. It then is the task of the firm "just" to identify and capture the resulting inventions. In recent years, however, a lead user method has been established that allows firms to systematically utilize the input of lead users for a given innovation problem (Lilien et al. 2002; Thomkelvon Hippel 2002; Churchill et al. 2009).

Lead users traditionally have relations with both firms and fellow users which are based on social-exchange, i.e. relations characterized by a non-monetary character. Research has shown that lead users frequently reveal their innovative ideas freely towards firms and other users. They do not want to profit from selling an innovation but from using a professional product produced by the receiving firm (Harhoff et al. 2003). In addition, their relationship to other users is social, too, due to the lack of economic interest and the lack of rivalry (Franke/Shah 2003; Füller et al. 2008). This non-rivalry has been illustrated by the pattern of pyramiding (e.g. Poetz/Pruegl 2010), when lead users often recommend other lead users who they believe to be better suited for a certain problem.

The introduction of social media may influence the lead user phenomenon within several dimensions. First, it could enhance collaboration among autonomous lead users due to informational gains and easier feedback from others. By e.g. using Youtube videos in order to show the application of prototypes, lead users can improve the trial and error process during the build phase. In addition, social media enables lead users to easily find likemined others who may have a piece of complementary information that is required to solve an innovation problem. As a result, lead users could achieve larger innovation outcomes with their own resources. The same effect also is true for firms searching for lead 
users. Professional social networks like LinkedIn or blogs provide perfect starting points for firms searching for lead users with specific characteristics, a process that in earlier times required a lot of time and research like an "investigative journalist" (Churchill et al. 2009). Hence, social media may improve the performance of a lead user activity.

However, the introduction of social media could also have negative consequences. In customer-firm relationships, the availability of social media could drive the likelihood of customers to become entrepreneurial, since it helps them to lower the market entry barriers that are often a reason for them to just give their idea to a professional firm (Harhoff et al. 2003; Lettl/Gemünden 2005). By using social media, lead users can more easily take on tasks like marketing and distribution, allowing them to skip co-creation activities with certain companies and to become entrepreneurs themselves, i.e. profiting from selling their innovation. Blogs featuring lead users turned entrepreneurs have created a strong notion of profit opportunities among participants. One could argue similar aspects for customercustomer relations, since social media could also lead to competition when entrepreneurial users start to competing with each other. This could actually lead to tensions, since the relation drifts to a hybrid between collaboration and competition (Hutter et al. 2011).

We propose the following questions for further research in this field: Social media could have a positive impact on co-creation with lead users. Further studies should investigate if and how social media could enhance the methods firms use for identifying lead users. What is its impact on identifying lead users by for example pyramiding within established social networks like LinkedIn or Xing? Does it also allow for a more efficient direct search? What are good starting points for a search in such a network? Which outlets and applications of social media are best suited to enhance this process? At the same time, social media may improve the problem solving skills of lead users. How do social media improve the trial-and-error-process of lead users by faster and better feedback from others? Do social media like virtual worlds even allow the efficient creation and testing of prototypes? Do social media applications create a new infrastructure that could provide lead users better access to solution information, allowing them to engage in larger and more complex tasks? Is there room and need for new social media applications, e.g. social toolkits, which could enhance such an activity?

At the same time, the applications of social media also may have a negative effect (from a firm perspective). Social media may signal lead users the potential commercial benefit of their inventions, hence lowering their willingness to freely reveal their invention. Does the introduction of social media lower co-creation willingness due to higher probability of entrepreneurial activities? Do social media also lower the interaction between lead uses as they perceive a kind of competition among themselves? Social media also allows the easier identification of lead users. Hence, the exclusivity of access to a specific lead user may be much more difficult to achieve for a firm when also its competitors can realize a lead user search more easily. The ability to perform co-creation with lead user may turn from a competitive advantage to a commodity, i.e. a common practice shared in one industry. Would such a development also motivate lead users to ask for a high monetary award for their contribution, turning them into a technical consultant?

\subsection{Social media impact on toolkits for customer co-design}

A very different method of co-creation is toolkits for customer co-design (von Hippel/Katz 2002; Franke/Piller 2003). The primary goal of toolkits is to access need information in a 
more efficient manner than possible through traditional means. They also aim at interacting with a large number of customers which often are "average" customers without lead user characteristics. A toolkit provides a development environment that enables customers to transfer their needs iteratively into a concrete solution. Following Franke and Schreier (2002), we distinguish two types of toolkits according to the degrees of freedom that the underlying solution space provides to customers: (1) toolkits for user innovation and (2) toolkits for user co-design and customization.

(1) Toolkits for user innovation resemble, in principle, a chemistry set. Their solution space or, at least some of the product's design parameters, is boundless. Toolkit users not only combine the manufacturer's standard modules and components to create the best possible product for themselves, but they also expend a tremendous amount of effort in experimenting through trial and error processes on new and up to now, unknown solutions for their needs. The manufacturer's toolkit provides the necessary solution information in the form of, for example, programming languages or drawing software. A good example comes from the semiconductor industry where firms equipped customers with toolkits for custom development of integrated circuits and computer chips (von Hippel/Katz 2002).

(2) On the other hand, toolkits for user co-design and customization are used for product individualization and adoption, rather than developing new goods and services. It can be compared to a set of Lego bricks. Toolkits for user co-design offer users more or less a large choice of individual building blocks (modules, components, parameters), which can be configured to make a product according to the user's individual requirements. Therefore, the toolkit's solution space is limited and can be modified only according to its predefined "building blocks". These building blocks lie within the range of a manufacturer's economic and technological capability (Franke et al. 2010; Franke/Schreier 2010). Wellknown examples of these types of toolkits are Dell's product configurator and configurators found, for example, in the automobile industry. Another example is LEGO Design$B y M e$, an advanced toolkit for user innovation targeting the children market.

While toolkits have been solely implemented in commercial markets, and are costly to develop, the interaction with customers on these toolkits are traditionally not characterized by monetary relations, but rather by social-exchange. Users of toolkits, especially in business to consumer markets, have been shown to enjoy the toolkit usage (Franke/Piller 2004; Ihl et al. 2006; Franke/Schreier 2010; Merle et al. 2010). Product co-designs by customers may also provide symbolic (intrinsic and social) benefits, resulting from the actual process of co-design rather than its outcome. Schreier (2006) quotes, for example, a prideof-authorship effect. Customers may co-create something by themselves, which may add value due to the sheer enthusiasm about the result. This effect relates to the desire for uniqueness, as discussed before, but here it is based on a unique task and not the outcome. In addition to enjoyment, task accomplishment has a sense of creativity. Participating in a co-design process may be considered a highly creative problem-solving process by the individuals engaged in this task (Ihl et al. 2006).

Social media can enhance customer co-design and may overcome some of its barriers. Earlier literature has shown that when a customer is exposed to myriad choices, the cost of evaluating those options can easily outweigh the additional benefit from having so many alternatives. The resulting syndrome has been called the "paradox of choice" (Schwartz 2004), in which too many options can actually reduce customer value instead of 
increasing it (Huffman/Kahn 1998). In such situations, customers might postpone their buying decisions and, worse, classify the vendor as difficult and undesirable (Dellaert/Stremersch 2005). Supplementing a toolkit with social media functionality may help. Piller et al. (2005) and Franke et al. (2008) have shown that communities can supplement toolkits. Social media allow to easily share a user design with peers and to get feedback. Also, user communities allow the publications of user generated design, hence providing inspiration and examples for an own design. Finally, social networking allows the integration of a peer into the actual co-design process, providing guidance and instant feedback. Using these social media applications may reduce the high cost of customer service that often companies are required to invest to support customers in co-design toolkits. All these relations are characterized by strong social exchange.

But at the same time, social media also could turn social relations more into "money markets", relying on economic exchange. A few websites that offer co-design toolkits actually have started to implement functionality for users to sell their creations to others. Examples include Zazzle, Spreadshirt, of Cafepress. On these websites, users can create a customized assortment of items and open a small online store to sell their creations to their peers and any other consumer. Social media allows users to link their creations easily to their network sites or post tweets about new creations, hence soliciting a commercial transaction within a previously private (social) context. For the manufacturer, this offers access to entirely new micro-markets that are created by their own users.

There are plenty of opportunities for further research to investigate the impact of this development. What are efficient design features of toolkits that allow manufacturers to profit from relationships among their customers based on social media? How does the implementation of social media and social commerce functionality affect customer behavior in co-design toolkits? How is the creation of hedonic value and process satisfaction different in toolkits that are enhanced by strong social media features to traditional toolkits that build on a 1:1 relation between the company and the customer? How do consumers utilize social media when becoming micro entrepreneurs, selling their creations in a toolkit among their peers? What are the incentive structures of these "customer entrepreneurs"? What are characteristics of commercially successful consumers that outperform other customers on the same co-design toolkit?

\subsection{Social media impact on solution contests (broadcast search)}

In many studies, innovation performance has been shown to be dependent on the ability of an organization to get access to new knowledge sources and to connect those with previous knowledge in an innovative way (Mansfield 1986). A core activity to achieve this goal is to establish broad networks with external entities. This exact process is facilitated by an open innovation approach called broadcast search, a kind of innovation contest (Jeppesen/Lakhani 2010). In an innovation contest, a company ("seeker") calls on its customers, users, or experts in the general public for a solution on a given technical challenge. This problem statement is "broadcasted" to a large open network in form of an open call with a request for proposals (solutions). Submissions by "solvers" are evaluated by a committee or intermediary with help of a performance scale, and the best solution is awarded either with a fixed award, a licensing contract for the technical innovation, or a developing contract (Reichwald/Piller 2009). 
Broadcast search has to be shown to be a highly efficient way to perform technical problem solving (Jeppesen/Lakhani 2010). Firstly, the open call for solutions enables a self-selection by potential solvers from any field. Often, the general class of the problem is known in different domains. A company, however, usually only looks for the "usual suspects" within its own network, biased by the seeker's own assumption about the character of the solution. In broadcast search, the requirement of defining the need in a general problem statement and the open request for proposals transmits the problem to representatives from often very different domains - with a different level of focus. Secondly, established intermediaries like NineSigma or Innocentive have a number of search specialists who use broad, unbiased search mechanisms to find potential solution providers around the world. The result is a much larger base of information that can be utilized for the innovation process. In a conventionally "closed" system of innovation, only information about solutions that is in the domain of the firm can be used as creative input for the innovation process, a problem that has been called the "local search bias" (Stuart/Podolny 1996). In an innovation system more open to external input, this knowledge stock is extended by the large base of information about needs, applications, and solution technologies that resides in the domain of customers, users, suppliers, experts, universities, and other external parties. Thus, just by increasing the potential pool of information, better results are become possible.

Broadcasting innovation problems to external participants in form of a "request for proposals" can clearly be recognized as an economic-exchange relation, both from the perspective of the firm-customer as well as the customer-customer relationships. On a first view, social media applications enhance the competition among participants as they allow the efficient broadcast to even a higher number of solvers, hence enlarging the field of competition, but also the potential quality of solvers. However, the introduction of social media could also alter these relations. First, it could change the customer-customer relationship drastically. Today, solvers typically do not know each other. Knowing each other however is a perquisite for engaging in collaboration between solvers. With the application of social media to connect problems and potential solvers openly, collaboration among solvers could foster individual problem solving performance, since potential solvers could support each other in a similar way as open source software communities do ( $\mathrm{La}$ khanilvon Hippel 2003). Contrary to this, however, a recent study of Boudreau et al. (2011) shows that increasing the number of solvers reduces the individual effort invested, thus influencing the customer-customer relationship negatively. However, this counts only for conditions of competition (as it currently is predominant in technical problem solving) which goes hand in hand with the economic-exchange relation between all actors. Thus it could be interesting to see if this effect is similar for collaboration, which could change the participant-participant relation into a more social form.

For companies seeking solutions, collaboration among solvers facilitated by social media also could be beneficial, since they could benefit from collaborative spillover effects among the solvers. Actually InnoCentive, one major provider of technical problem solving services, started to incorporate collaborative tools in their service offering, like for example "Innocentive@work". Although this service is focusing on solvers within one specific company, it also could be valuable to examine if, and for which kind of challenges, the collaborative features enhance the efficiency of the problem solving process (e.g. shorten- 
ing time) or enhance the achieved output (e.g. solving more problems or solving problems better).

On the other hand, the introduction of social media is also associated with several risks for seekers. For many service providers offering broadcast search, their solver community is a key asset. If the members of the community become more visible through usage of social media (e.g. by using a Facebook group), it could actually harm the intermediaries' business model, since the solver community could be addressed by solution seekers directly without the intermediary. This disruptive disadvantage from the intermediary's perspective however could become a benefit for the focal company as it would not need to pay a fee to the intermediary for its services.

Wrapping this up, a number of interesting research questions derive from the integration of social media in the field of co-creation via broadcast search: How does the usage of social media enhance the ability of a given network of potential solvers to generate a solution? When do solvers use social networking to inform their peers about an open problem? What incentives can motivate such a behavior? Can social media also induce collaboration among solvers and thus enhance the technical problem solving capacity of a network? Are there specific kinds of challenges that benefit more from collaboration than others? How is such collaboration influencing the competitive nature that is characterizing an innovation contest conventionally? Do social media applications enforce competition among solvers and thus lead to a decrease in the effort invested by an individual solver? Does the introduction of social media undermine the business model of intermediaries operating innovation contests, since it allows seeker to get in contact with solvers directly? And what are the implications for intellectual property (IP) arrangements like patents or licensing contracts when multiple solvers contribute to one problem solution? Does the use of social media hence imply the creation of "social IP"?

\subsection{Social media impact on ideation contests}

A final method of co-creation also takes the form of an innovation contest, but one for ideas and not for technical solutions. Ideation contests want to generate novel concepts and ideas (Piller/Walcher 2006; Ebner et al. 2009; Bullinger et al. 2010). In an ideation contest, a firm seeking innovation-related information posts a request to a population of independent, competing agents (e.g. customers), asking for solutions to a given task within a given timeframe. The firm then provides an award to the participants that generate the best solutions. A solution reward is important in the early stages of an innovation process because at this stage customers are unlikely to benefit directly from their contributions through new product availability within a short time frame.

Some companies promise cash rewards or licensing contracts for innovative ideas, others build on non-monetary acknowledgments - promising peer or company (brand) recognition that facilitates a pride-of-authorship effect. Obviously, rewards or recognitions are not given to everyone submitting an idea, but only to those with the "best" submissions. This competitive mechanism is an explicit strategy to foster customer innovation. It should encourage more or better customers to participate, should inspire their creativity, and increase the quality of the submissions. For instance, over 120,000 individuals around the world served as voluntary members of Boeing's World Design Team, contributing input to the design of its new 787 Dreamliner airplane (www.newairplane.com). Today we find a broad range of ideation contests in practice. A good starting point to ex- 
plore this field is www.innovation-community.de, a site listing more than 80 ideation contests. These can be differentiated according to the degree of problem specification, i.e. does the problem clearly specify the requirements for the sought solution or is it more or less an open call for input to a vaguely specified problem.

Similar to broadcast search, ideation contests can be characterized as economicexchange relationship due to their extrinsic incentive mechanism and competitive character (Piller/Walcher 2006). In fact, most prior research on ideation contests highlighted the utter impact of monetary rewards as a reason for customer participation (Füller 2010). However, in contrast to technical problem solving contests, awards in ideation contests tend to be significantly lower and participants have to compete against many more others in order to win them. This indicates that other motives apart from strictly rational reasons influence participants in their behavior. This counts especially for the customer-firm relationship, since economic theory fails to explain why participants invest time and effort when their expected monetary outcome from doing so is relatively low.

In addition, in many ideation contests, customer-customer relationships are clearly more social than for technical problem solving, although participants are still competitors. In many ideation contests, participants see each other and each other's ideas, provide comments, evaluations, and feedback on ideas, or even versionate existing ideas - hence they engage in collaborative activities. Providers of ideation contests like Munich-based Hyve or Paris-based $e Y e k a$ have recently integrated an entire range of collaboration features to enable and further encourage this behavior. They even have started to incentivize social relationships by monetary awards in form of a "most active participant" or "most active commentator" award. This opens many interesting questions for future research in the field of these hybrid incentive structures that intuitively contradict each other.

Recent research on this issue has found that idea contests work best with either participants with very high cooperative orientation or with those with a very low one (Bullinger et al. 2010; Hutter et al. 2011). This ambiguity becomes especially relevant when introducing additional social media aspects. However, the introduction of social media on customer-customer relationship as well as customer-firm relationship could have similar effects as in technical problem solving, since for both segments it enables or enhances collaboration. Social media could also be beneficial for the firm-customer relationship, since customers motivation could be fostered by the recognition of the firm. Also, social media usage (like e.g. creating an exclusive Facebook group with specific events) could have effects on customers similar to empowerment strategies in terms of higher product demand (Fuchs et al. 2010) and a higher brand attachment (Fuchs/Schreier 2011).

Again, there also may be possible downsides of the introduction of social media. As highlighted above, monetary incentives are not the sole driver of participation (Füller 2010). Non-monetary incentives of participants could be fostered by the introduction of social media. While this sounds beneficial on the first glimpse, it also could bear some risks; since it could happen that the host loses control of the initiative. Customers could use the co-creation method to discuss topics they favor and not act in the best interest of the host. If the host tries to govern the topics of the contest against the will of the customers, they could actually leave the contest and switch to social media offers and continue their creative effort there, which leaves the host with fewer participants. Also, there have been recent examples where participants used social media to intentionally interfere with 
an ideation contest by posting destructive contributions (as recent examples of idea contests hosted by Henkel or Otto Group have demonstrated).

Concluding, we propose the following research questions that may be helpful to further study the role of social media for ideation contests. Can social media applications induce more favorable corporate attitudes and thus enhance the participation effort of participants? How do social media influence the different motives for participation in an ideation contests that lead to superior results for the host in terms of more or better ideas? Can economic incentives successful foster engagement in social-exchange relationships? Does the introduction of social media lower the degree of control the host has concerning topics of the ideation contests? Do social media applications foster a "hacking" of contests and their use for destructive behavior of participants? Can firms themselves use social media to prevent or counterbalance such behavior?

\section{Conclusions and outlook}

In this paper, we have provided a conceptual, theoretical based model for the impact of social media in innovation processes based on customer co-creation. As we have seen, social media may enhance the effectiveness and the efficiency of co-creation by lowering the cost of interaction among participants and by allowing a larger number of participants to contribute to a particular co-creation initiative, hence enhancing the heterogeneity of knowledge stocks in the participant community - a core factor of success in innovation management (Laursen/Salter 2006).

But we also have shown that social media may change the character of co-creation applications. Figure 2 summarizes our argumentation. For forms of co-creation that used to be characterized by social-exchange, like the lead user method, social media may introduce a stronger emphasis of monetary-exchange relations. The U.S. company Quirky is a particular example of such a development. Quirky has made the transfer from lead user ideas into actual products the core of its business model. It actually created a market place for lead user ideas. It is entirely based on social media, hence turning product development into social product development (Piller 2010). These products include electronic gadgets, travel goods, and household items. Quirky engages its community in activities along the entire span of the innovation process, including its financing. A project starts when a lead user suggests a new product idea. The Quirky community then votes on the ideas that should enter the next stage of development, where ideas are jointly turned into a more developed product by the community and by Quirky's own developers. This development is followed by another evaluation. If passed, the staff works with manufacturers and suppliers to specify a price, and the concept is out for community financing. If the product receives enough online preorders, it goes into production (the process is outlined at http:// www.quirky.com/learn).

Quirky currently is one of the best examples of co-creation in a firm-organized community. The site provides a platform for products originating from deep user insights, offering anyone the opportunity of turning ideas into real products at low cost. Also, an inventor whose idea does not make it to a final stage gets plenty of feedback from others on the idea. However, Quirky motivates its community not by intrinsic incentives, but predominantly uses monetary relations. It has created a pure "money market" for community based innovation. About 30 percent of the gross sales revenues of each product are distributed among the participants. According to its founder, the core challenge when 
launching the company was developing an algorithm that provides a fair distribution of $30 \%$ of all revenues to the community members who contributed to a particular project (Piller 2010). In average, 800-1200 contributors are paid per product. Payments are openly revealed on the website for each product and contributor, hence creating monetary rankings of participants. While such a large-scale contribution scheme still is very rare, it could become a role model for the co-creation economy. Social media here has changed originally social-relations into money-relations.

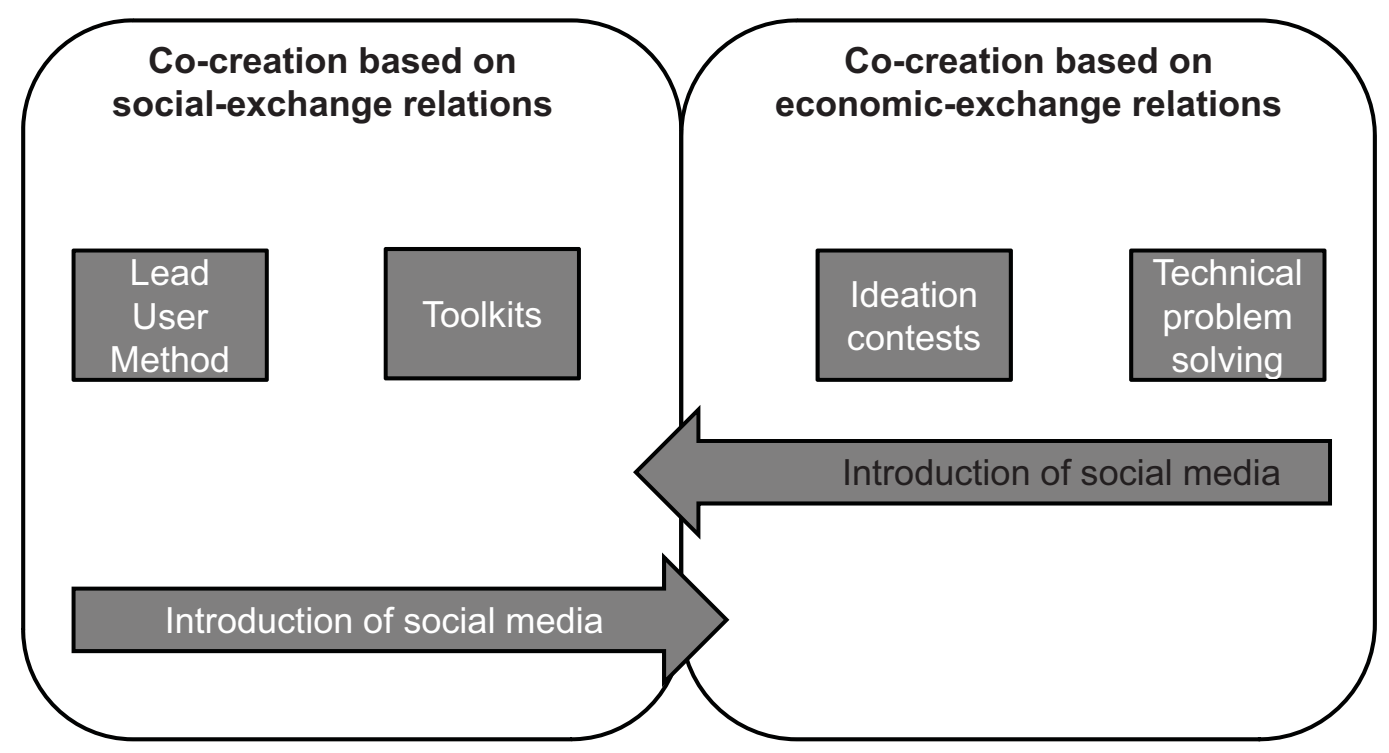

Figure 2: Impact of social media on market relationships of co-creation

Another example of turning co-creation models based on economic-exchange relations into social-exchange relations are more "socially-focused" idea contests, like for example Scraplab (http://www.scraplab.org) which aims at developing concepts on how to foster ecologic product development. Next to this, more and more governmental organizations are using their "citizens" to co-create certain tasks and decisions, also relying deeply on their willingness to engage in social relations rather than in economic ones. These hosts use their non-profit character to trigger more social-exchange behavior, hoping for larger participant numbers at a low cost of hosting and organizing the co-creation activity.

Beyond the application of social media for co-creation, also the different methods of cocreation per se still offer plenty of opportunities for further research (Piller et al. 2011). First, firms need information and better guidance on how to assess if their organization and branch is suited for customer co-creation. This information is crucial in order to build specific competences that aid firms at identifying opportunities and ultimately at using the right method. Managers need a clear picture of their own organizational settings and capabilities before being able to answer important questions during the implementation of one's own customer integration initiative. This could include answers to questions like how do innovation projects have to be reorganized, which kinds of projects are suited for 
customer integration and how do the internal development processes have to be adjusted in order to allow optimal customer co-creation.

Secondly, previous research focused on showing the application of customer co-creation, mostly in terms of successful examples. These examples are valuable for creating evidence and generating attention for the phenomena, but often lack a differentiated perspective on the chosen co-creation method. To bring the discussion on methods to the next level, more research on specific design components of these methods are mandatory in order to provide information how the method is used in the best way. For example, while the motives of customers participating in firm-hosted co-creation activities have recently been subject for a considerable extent of research (see e.g. Füller et al. 2008; Füller 2010), the ways how to design a specific method remain relatively vague. Future contributions to these aspects need to give an answer to questions like how to design the methods in order to attract the desired participants or to evoke the preferred behavior. Future research also has to investigate how a firm can influence the output of the open innovation activities by adjusting these specific design factors.

Finally, research is needed on the long-term effects of customer co-creation on competition. Today, co-creation with customers is booming. The number of firms and even governments implementing co-creation is steadily growing. This growth in numbers generates lots of opportunities for researchers to acquire empirical data from these activities, which may be used to answer some of the questions proposed above. But this growth also has its downsides. With more and more firms hosting co-creation activities, innovative customers could become a scarce good, for which companies have to compete for in order to get them into "their" activities. As we have argued, social media applications may foster this development further. Ultimately, this could result in a shortage of the former infinite resource, the "customer crowd", adding a new facet to firms' competition among customers. Modeling the effect of customer co-creation and the scare resource of "innovative users" could become a fascinating field for future research in economics, strategy, and social media research.

\section{References}

Bartl, M./Ivanovic, I. (2010): Netnography - Finding the right balance between automated and manual research, in: Brauckmann, P. (Hrsg.): Web-Monitoring, Konstanz, S. 157-174.

Boudreau, K.J./Lakhani, K.R./Lacetera, N. (2011): Incentives and Problem Uncertainty in Innovation Contests: An Empirical Analysis, in: Management Science, Vol. 57, No. 5, S. 843-863.

Bullinger, A.C./Neyer, A.K./Rass, M./Moeslein, K.M. (2010): Community-Based Innovation Contests: Where Competition Meets Cooperation, in: Creativity and Innovation Management, Vol. 19, No. 3, S. 290-303.

Cassiman, B./Veugelers, R. (2006): In search of complementarity in innovation strategy: Internal R\&D and external knowledge acquisition, in: Management Science, Vol. 52, No. 1, S. 68-82.

Chesbrough, H.W. (2003): Open Innovation: The New Imperative for Creating and Profiting from Technology, Boston, MA.

Chesbrough, H.W./Crowther, A.K. (2006): Beyond high tech: Early adopters of open innovation in other industries, in: R\&D Management, Vol. 36, No. 3, S. 229-236.

Churchill, J./von Hippel, E./Sonnack, M. (2009): Lead User Project Handbook. A practical guide for lead user project teams, http://web.mit.edu/evhippel/www/tutorials.htm, Zugriff: 14.12.2011. 
Cortizo, J./Carrero, F.M./Gomez, J.M. (2011): Introduction to the Special Issue: Mining Social Media, in: International Journal Of Electronic Commerce, Vol. 15, No. 3, S. 5-8.

Culnan, M.J./McHugh, J./Zubillage, J.I. (2010): How large U.S. companies can use twitter and other social media to gain business value, in: MIS Quarterly Executive, Vol. 9, No. 4, S. 243-259.

Dahan, E./Hauser, J.R. (2002): The virtual customer, in: Journal of Product Innovation Management, Vol. 19, No. 5, S. 332-353.

Dellaert, B.G.C./Stremersch, S. (2005): Marketing Mass Customized Products: Striking a Balance between Utility and Complexity, in: Journal of Marketing Research, Vol. 42, No. 2, S. 219-227.

di Gangi, P.M./Wasko, M./Hooker, R. (2010): Getting Customers' Ideas to Work for You: Learning from Dell How to Succeed with Online User Innovation Communities, in: MIS Quarterly Executive, Vol. 9, No. 4, S. 213-228.

Diener, K./Piller, F. (2010): The Market for Open Innovation, Raleigh, NC.

Dolan, R.J./Matthews, J.M. (1993): Maximizing the utility of customer product testing: Beta test design and management, in: Journal of Product Innovation Management, Vol. 10, No. 4, S. 318-330.

Ebner, W./Leimeister, J.M./Krcmar, H. (2009): Community Engineering for Innovations - The Ideas Competition as a method to nurture a Virtual Community for Innovations, in: R\&D Management, Vol. 39, No. 4, S. 342-356.

Fiske, A.P. (1992): The Four Elementary Forms of Sociality: Framework for a Unified Theory of Social Relations, in: Psychological Review, Vol. 99, No. 4, S. 689-723.

Franke, N./Keinz, P./Schreier, M. (2008): Complementing mass customization toolkits with user communities: How peer input improves customer self-design, in: Journal of Product Innovation Management, Vol. 25, No. 6, S. 546-559.

Franke, N./Schreier, M./Kaiser, U. (2010): The "I Designed It Myself" Effect in Mass Customization, in: Management Science, Vol. 56, No. 1, S. 125-140.

Franke, N./Piller, F.T. (2003): Key research issues in user interaction with user toolkits in a mass customisation system, in: International Journal of Technology Management, Vol. 26, No. 5, S. 578-599.

Franke, N./Piller, F.T. (2004): Toolkits for user innovation and design: An exploration of user interaction and value creation, in: Journal of Product Innovation Management, Vol. 21, No. 6, S. 401-415.

Franke, N./Schreier, M. (2002): Entrepreneurial opportunities with toolkits for user innovation and design, in: International Journal on Media Management, Vol. 4, No. 4, S. 225-234.

Franke, N./Schreier, M. (2010): Why customers value self-designed products: The importance of process effort and enjoyment, in: Journal of Product Innovation Management, Vol. 27, No. 4, S. 1020-1031.

Franke, N./Shah, S. (2003): How communities support innovative activities: An exploration of assistance and sharing among end-users, in: Research Policy, Vol. 32, No. 1, pp. 157-178.

Fredberg, T./Piller, F.T. (2011): The paradox of tie strength in customer relationships for innovation: A longitudinal case study in the sports industry, in: R\&D Management, Vol. 41, No. 5, S. 470-484.

Fuchs, C./Schreier, M./Prandelli, E. (2010): The Psychological Effects of Empowerment Strategies on Consumers' Product Demand, in: Journal of Marketing, Vol. 74, No. 1, S. 65-79.

Fuchs, C./Schreier, M. (2011): Customer Empowerment in New Product Development, in: Journal of Product Innovation Management, Vol. 28, No. 1, S. 17-32. 
Füller, J. (2010): Refining Virtual Co-Creation from a Consumer Perspective, in: California Management Review, Vol. 52, No. 2, S. 98-122.

Füller, J./Matzler, K./Hoppe, M. (2008): Brand community members as a source of innovation, in: Journal of Product Innovation Management, Vol. 25, No. 6, S. 608-619.

Gallaugher, J./Ransbotham, S. (2010): Social Media and Customer Dialog Management at Starbucks, in: MIS Quarterly Executive, Vol. 9, No. 4, S. 197-212.

Griffin, A./Hauser, J.R. (1993): The voice of the customer, in: Marketing Science, Vol. 12, No. 1, $1-27$.

Harhoff, D./Henkel, J./von Hippel, E. (2003): Profiting from voluntary information spillovers: How users benefit by freely revealing their innovations, in: Research policy, Vol. 32, No. 10, S. 1753-1769.

Hennig-Thurau, T./Gwinner, K.P./Walsh, G./Gremler, D.D. (2004): Electronic word-of-mouth via consumer-opinion platforms: What motivates consumers to articulate themselves on the Internet?, in: Journal of Interactive Marketing, Vol. 18, No. 1, S. 38-52.

Heyman, J./Ariely, D. (2004): Effort for payment. A tale of two markets, in: Psychological Science, Vol. 15, No. 11, S. 787-793.

Huffman, C./ Kahn, B.E. (1998): Variety for Sale: Mass Customization or Mass Confusion?, in: Journal of Retailing, Vol. 74, No. 4, S. 491-513.

Hutter, K./Hautz, J./Füller, J./Mueller, J./Matzler, K. (2011): Communitition: The tension between competition and collaboration in community-based design contests, in: Creativity and Innovation Management, Vol. 20, No. 1, S. 3-21.

Ihl, C./Müller, M./Piller, F./Reichwald, R. (2006): Kundenzufriedenheit bei Mass Customization: Eine empirische Untersuchung zur Bedeutung des Co-Design-Prozess aus Kundensicht, in: Die Unternehmung, Vol. 59, No. 3, S. 165-184.

Jeppesen, L.B./Lakhani, K.R. (2010): Marginality and Problem-Solving Effectiveness in Broadcast Search, in: Organization Science, Vol. 21, No. 5, S. 1016-1033.

Kaplan, A.M./Haenlein, M. (2010): Users of the world, unite! The challenges and opportunities of Social Media, in: Business Horizons, Vol. 53, No. 1, S. 59-68.

Kietzmann, J.H./Hermkens, K./McCarthy, I.P./Silvestre, B.S. (2011): Social media? Get serious! Understanding the functional building blocks of social media, in: Business Horizons, Vol. 54, No. 3, S. 241-251.

Kozinets, R.V. (1998): The field behind the screen: Using netnography for marketing research in online communities, in: Journal of Marketing Research, Vol. 39, No. 1, S. 61-72.

Kozinets, R.V. (2002): On Netnography: Initial reflections on consumer research investigations of cyberculture, in: Alba, J.W./ Hutchinson J.W. (Hrsg.): Advances in Consumer Research, Vol. 25, Provo, UT, S. 366-371.

Lakhani, K./von Hippel, E. (2003): How open source software works: "free" user-to-user assistance, in: Research Policy, Vol. 32, No. 6, S. 923-943.

Langer, R./Beckman, S.C. (2005): Sensitive research topics: Netnography revisited, in: Qualitative Market Research, Vol. 8, No. 2, S. 189-203.

Laursen, K./Salter, A. (2006): Open for innovation: The role of openness in explaining innovation performance among UK manufacturing firms, in: Strategic Management Journal, Vol. 27, No. 2, S. 131-150.

Lettl, C./Gemünden, H.G. (2005): The entrepreneurial role of innovative users, in: Journal of Business \& Industrial Marketing, Vol. 20, No. 7, S. 339-346. 
Lilien, G. L./Morrison, P.D./Searls, K./Sonnack, M./von Hippel, E. (2002): Performance assessment of the lead user idea-generation process for new product development, in: Management Science, Vol. 48, No. 8, S. 1042-1059.

Mansfield, E. (1986): Patents and innovation: An empirical study, in: Management Science, Vol. 32, No. 2, S. 173-181.

Merle, A./Chandon, J.-L./Roux, E./Alizon, F. (2010): Perceived Value of the Mass-Customized Product and Mass Customization Experience for Individual Consumers, in: Production and Operations Management, Vol. 19, S. 503-514.

O'Hern, M.S./Rindfleisch, A. (2009): Customer co-creation: A typology and research agenda, in: Malhotra, N.K. (Hrsg.): Review of Marketing Research, Vol. 6, Armonk, NY, S. 84-106.

Ogawa, S. (1998): Does sticky information affect the locus of innovation? Evidence from the Japanese convenience-store industry, in: Research Policy, Vol. 26, No. 7-8, S. 777-790.

Piller, F.T. (2004): Innovation and Value Co-Creation. Habilitationsschrift an der Fakultät für Wirtschaftswissenschaften der Technischen Universität München.

Piller, F.T. (2010): Ten Reasons Why I Consider Quirky.com As Best in Crowdsourcing and Open Innovation, http://tinyurl.com/37boopb, Zugriff: 14.10.2011.

Piller, F.T./Ihl, C. (2010): Open Innovation with Customers - Foundations, Competences and International Trends, Expert Study commissioned by the European Union, The German Federal Ministry of Research, and Europäischer Sozialfond ESF, Aachen.

Piller, F.T./Ihl, C./Vossen, A. (2011): Customer Co-Creation: Open Innovation with Customers, in: Wittke, V./Hanekop, H. (Hrsg.): New Forms of Collaborative Innovation and Production on the Internet, Göttingen, S. 31-63.

Piller, F.T./Schubert, P./Koch, M./Möslein, K. (2005): Overcoming Mass Confusion: Collaborative Customer Co-Design in Online Communities, in: Journal of Computer-Mediated Communication, Vol. 10, No. 4, http://jcmc.indiana.edu/vol10/issue4/piller.html, Zugriff: 10.12.2011.

Piller, F.T./Walcher, D. (2006): Toolkits for idea competitions: A novel method to integrate users in new product development, in: R\&D Management, Vol. 36, No. 3, S. 307-318.

Poetz, M.K./Pruegl, R. (2010): Crossing Domain-Specific Boundaries in Search of Innovation: Exploring the Potential of Pyramiding, in: Journal of Product Innovation Management, Vol. 27, No. 6, S. 897-914.

Prahalad, C.K./Ramaswamy, V. (2004): The Future of Competition: Co-Creating Unique Value with Customers, Boston.

Ramirez, R. (1999): Value co-production: Intellectual origins and implications for practice and research, in: Strategic Management Journal, Vol. 20, No. 1, S. 49-65.

Reichwald, R./Piller, F.T. (2009): Interaktive Wertschöpfung: Open Innovation, Individualisierung und neue Formen der Arbeitsteilung (2. Aufl.), Wiesbaden.

Roser, T./Samson, A./Humphreys, P./Cruz-Valdivieso, E. (2009): New pathways to value: Co-creating products by collaborating with customers, London.

Schreier, M. (2006): The value increment of mass-customized products: An empirical assessment, in: Journal of Consumer Behavior, Vol. 5, No. 4, S. 317-327.

Schumpeter, J.A. (1942): Capitalism, socialism and democracy, New York.

Schwartz, B. (2004): The Paradox of Choice - Why More Is Less, New York.

Seybold, P. (2006): Outside Innovation, New York.

Stuart, T.E./Podolny, J.M. (1996): Local search and the evolution of technological capabilities, in: Strategic Management Journal, Vol. 17, No. 1, 21-38. 
Tapscott, D./Williams, A.D. (2006): Wikinomics: How Mass Collaboration Changes Everything, New York.

Terwiesch, C./Xu, Y. (2008): Innovation contests, open innovation, and multiagent problem solving, in: Management Science, Vol. 54, No. 9, S. 1529-1543.

Thomke, S. (2003): Experimentation Matters: Unlocking the Potential of New Technologies for Innovation, Boston.

Thomke, S./von Hippel, E. (2002): Customers as innovators: A new way to create value, in: Harvard Business Review, Vol. 80, No. 4, S. 74-81.

Tripp, T.M./Grégoire, Y. (2011): When Unhappy Customers Strike Back on the Internet, in: MIT Sloan Management Review, Vol. 52, No. 3, S. 37-44.

von Hippel, E. (1978): A customer-active paradigm for industrial product idea generation, in: Research Policy, Vol. 7, No. 3, S. 240-266.

von Hippel, E. (1988): The sources of innovation, New York.

von Hippel, E. (1998): Economics of product development by users: The impact of 'sticky' local information, in: Management Science, Vol. 44, No. 5, S. 629-644.

von Hippel, E. (2005): Democratizing Innovation, Cambridge.

von Hippel, E./Katz, R. (2002): Shifting innovation to users via toolkits, in: Management Science, Vol. 48, No. 7, S. 821-833.

von Hippel, E./von Krogh, G. (2003): Open Source Software and the Private-Collective Innovation Model: Issues for Organization Science, in: Organization Science, Vol. 14, No. 2, S. 209-223.

von Hippel, E./von Krogh, G. (2006): Free revealing and the private collective model for innovation incentives, in: R\&D Management, Vol. 36, No. 3, S. 295-306.

Wikström, S. (1996): Value creation by company-consumer interaction, in: Journal of MarketingManagement, Vol. 12, S. 359-374.

Frank Piller, Prof. Dr., ist Inhaber des Lehrstuhls für Technologie- und Innovationsmanagement an der RWTH Aachen.

Alexander Vossen, Dipl.-Kfm., ist wissenschaftlicher Mitarbeiter und Doktorand am Lehrstuhl für Technologie- und Innovationsmanagement an der RWTH Aachen.

Christoph Ihl, Dr., ist Habilitand am Lehrstuhl für Technologie- und Innovationsmanagement an der RWTH Aachen.

Anschrift: RWTH Aachen, Lehrstuhl TIM, Templergraben 55, 52056 Aachen, Tel.: +49(0) 241/809-577, E-Mails: piller@tim.rwth-aachen.de, vossen@tim.rwth-aachen.de, ihl@tim.rwth-aachen.de 